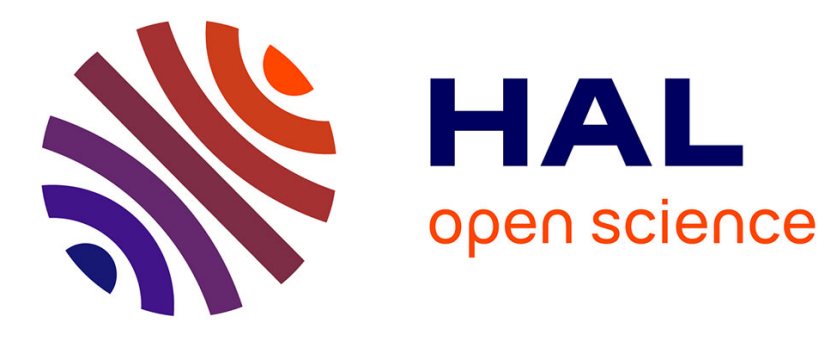

\title{
Effect of supercritical carbon dioxide on polystyrene extrusion
}

Martial Sauceau, Clémence Nikitine, Élisabeth Rodier, Jacques Fages

\section{To cite this version:}

Martial Sauceau, Clémence Nikitine, Élisabeth Rodier, Jacques Fages. Effect of supercritical carbon dioxide on polystyrene extrusion. Journal of Supercritical Fluids, 2007, 43 (2), pp.367 - 373. 10.1016/j.supflu.2007.05.014 . hal-01829541

\section{HAL Id: hal-01829541 https://imt-mines-albi.hal.science/hal-01829541}

Submitted on 17 Jul 2018

HAL is a multi-disciplinary open access archive for the deposit and dissemination of scientific research documents, whether they are published or not. The documents may come from teaching and research institutions in France or abroad, or from public or private research centers.
L'archive ouverte pluridisciplinaire HAL, est destinée au dépôt et à la diffusion de documents scientifiques de niveau recherche, publiés ou non, émanant des établissements d'enseignement et de recherche français ou étrangers, des laboratoires publics ou privés. 


\title{
Effect of supercritical carbon dioxide on polystyrene extrusion
}

\author{
M. Sauceau*, C. Nikitine, E. Rodier, J. Fages \\ RAPSODEE Research Centre, UMR EMAC-CNRS 2392, École des Mines d'Albi, 81013 Albi, France
}

\begin{abstract}
A study on the extrusion of polystyrene was carried out using supercritical carbon dioxide $\left(\mathrm{scCO}_{2}\right)$ as foaming agent. $\mathrm{scCO}_{2}$ modifies the rheological properties of the material in the barrel of the extruder and acts as a blowing agent during the relaxation at the passage through the die. For experiments, a single-screw extruder was modified to be able to inject $\mathrm{scCO}_{2}$ within the extruded material. The effect of operating parameters on material porosity was studied. Samples were characterized by using water-pycnometry, mercury-porosimetry and scanning electron microscopy. Polystyrene with expansion rate about $15-25 \%$ was manufactured. A rapid cooling just downstream the die is important to solidify the structure. The die temperature allows the control of the porosity structure. $\mathrm{CO}_{2}$ concentration shows no significant influence.
\end{abstract}

Keywords: Polystyrene; Polymer; Foam; Extrusion; Supercritical carbon dioxide

\section{Introduction}

Extrusion is a process of converting a raw material into a product of uniform shape and density by forcing it through a die under controlled conditions [1]. Industrial applications of the extrusion process dates back to the 1930s. It is extensively applied in the plastic and rubber industries, where it is one of the most important manufacturing processes. A particular application concerns the built up of polymeric foams. Conventional foamed products are produced using either chemical or physical blowing agents. Various chemical blowing agents, which are generally low molecular weight organic compounds, are mixed into a polymer matrix and decompose when heated beyond a threshold temperature. This results in the release of a gas, and thus the apparition of bubbles. This implies however the presence of residues in material and the need for an additional stage to eliminate them. Techniques using physical agents include the mixing of a gas with melted polymer. Then, a thermodynamic instability is induced through a pressure or temperature change to nucleate bubbles of the blowing agent. After nucleation, the bubble growth is controlled by reducing the temperature below the glass transition temperature of the polymer.

A supercritical fluid (SCF) is defined as a substance for which both pressure and temperature are above the critical

\footnotetext{
* Corresponding author. Tel.: +335634933 18; fax: +33563493243.

E-mail address: martial.sauceau@enstimac.fr (M. Sauceau).
}

value. In general, SCFs offer mass transfer advantages over conventional organic solvents because of their gas-like diffusivity, liquid-like density, low viscosity and surface tension [2]. In particular, supercritical carbon dioxide $\left(\mathrm{scCO}_{2}\right)$ has emerged as an important SCF due to its many desirable attributes such as low cost, non-toxicity, non-flammability, chemical inertia and easily accessible supercritical conditions $\left(T_{\mathrm{c}}=31.1^{\circ} \mathrm{C}\right.$, $P_{\mathrm{c}}=7.38 \mathrm{MPa}$ ). When $\mathrm{CO}_{2}$ is raised above its critical point, its physicochemical properties can be continuously tuned between vapour-like and liquid-like limits by varying the system pressure and/or temperature. Moreover, $\mathrm{scCO}_{2}$ has been widely used in polymer processing $[3,4]$ as it is possible to dissolve large quantities of $\mathrm{CO}_{2}$ in a variety of polymers [5,6]. This involves in particular the swelling and the plasticization of the polymer, inducing changes in mechanical and physical properties [3]. For instance, $\mathrm{scCO}_{2}$ decreases the glass transition temperature, the interfacial tension or the viscosity of various polymers, without changing the viscoelastic behaviour [7]. With polystyrene (PS), the glass transition temperature decreases from $105^{\circ} \mathrm{C}$ to $98^{\circ} \mathrm{C}$ and to $46.4{ }^{\circ} \mathrm{C}$ with a $\mathrm{CO}_{2}$ mass fraction of 1 and $5.9 \%$, respectively [8] and the interfacial tension decreases linearly from 28 to $17 \mathrm{~mJ} \mathrm{~m}^{-2}$ on a $\mathrm{CO}_{2}$ pressure range from 1 to $10 \mathrm{MPa}$ at $200^{\circ} \mathrm{C}$ $[9,10]$.

The presence of $\mathrm{scCO}_{2}$ in extrusion process modifies rheological properties of the polymer in the barrel of the extruder and acts as a blowing agent during the relaxation at the passage through the die. Thus, its high solubilization in the polymer results in extensive expansion at the die. The reduction of 
viscosity decreases the mechanical constraints and the operating temperature within the extruder.

In classical theory, the homogeneous nucleation rate (i.e. the number of cells created per units of time and volume) can be expressed as a function of the Gibbs free energy barrier for the formation of a critical bubble nucleus and temperature [11]. The theory suggests that the energy barrier and the interfacial tension decrease as the supersaturation pressure increases. Consequently, the homogeneous nucleation rate increases and a large number of small cells is obtained. In fact, controlling supercritical $\mathrm{CO}_{2}$ quantity allows the modification of the cell density and the cell size in microcellular foaming.

The objective of this work is to develop a process of extrusion coupled with the use of $\mathrm{scCO}_{2}$. In a preliminary work, an extruder was modified in order to be able to inject $\mathrm{scCO}_{2}$ within the extruded material and some experiments were performed on polystyrene (PS) [12]. A pressure decrease within the extruder was observed upon $\mathrm{CO}_{2}$ injection and samples of porous PS were obtained, with a decrease of their apparent density from 30 to $40 \%$. However, the porous structure was irregular, with bubble diameters varying from $100 \mu \mathrm{m}$ to $1 \mathrm{~mm}$. This could be explained considering the quality of the mixture in the extruder. Indeed, an insufficient homogeneity of mixture PS- $\mathrm{CO}_{2}$ could explain the irregularity of porosity. Therefore, the experimental device has been modified in order to improve the mixture between the two components. In this work, this novel device has been tested with PS and the influence of cooling, die temperature and $\mathrm{CO}_{2}$ content on the material properties has been studied.

\section{Experimental}

\subsection{Materials and equipment}

Polystyrene (choc, BP Chemicals) was used in experiments and $\mathrm{CO}_{2}$ (N45, Air Liquide) was applied as the physical foaming agent.
Fig. 1 shows the flow diagram of the foaming system. The extruder used in this study is a single-screw machine with a $20 \mathrm{~mm}$ screw diameter and a length to diameter ratio $(L / D)$ of 20 (Rhéoscam, SCAMEX). Carbon dioxide is pumped from a cylinder by a syringe pump (260D, ISCO), which allows the delivery of small flow rates (i.e. $0.1 \mu \mathrm{l} \mathrm{mn^{-1 }}$ ). The pump is run in constant volumetric flow rate mode and $\mathrm{CO}_{2}$ is introduced at the same pressure as the pressure prevailing in the extruder. The injection position is located at about $12 \mathrm{D}$ from hopper, in a zone where the screw diameter is constant. A checking valve is inserted in the line to prevent pollution of $\mathrm{CO}_{2}$. The polymer- $\mathrm{CO}_{2}$ mixture is then passed through a mixer (type 'pineapple'), composed of diamond spike. This element, inserted before the die, provides a dynamic distributive mixing between the two components [13]. The pressure drop through the die can be adjusted by modifying restriction opening by means of a screw placed in the polymer flow.

The pressure, the temperature and the volumetric $\mathrm{CO}_{2}$ flow rate are measured within the syringe pump. $\mathrm{CO}_{2}$ density is obtained by Peng Robinson's equation of state [14]. In operating conditions used, $\mathrm{CO}_{2}$ concentration is always smaller than saturation concentration. Consequently, polystyrene- $\mathrm{CO}_{2}$ blend is in a single phase at thermodynamic equilibrium $[15,16]$.

The temperature inside the barrel is regulated at four locations: $T_{1}, T_{2}$ before and after the $\mathrm{CO}_{2}$ injection, $T_{3}$ before the mixing element and $T_{4}$ before the die. Only the temperature of the die $T_{4}$ is changed at each experiment. Three other temperatures and screw speed are kept constant at $180^{\circ} \mathrm{C}$ and $50 \mathrm{rpm}$, respectively. At each new condition, temperature $T_{\text {mat }}$ and pressure $P_{\text {mat }}$ of material are measured just before entry within the die. The flow rate of polymer $Q_{\text {mat }}$, of the order of $0.6 \mathrm{~kg} \mathrm{~h}^{-1}$, is obtained by weighing the extrudate at the end of the experiment. $\mathrm{CO}_{2}$ concentration $C_{\mathrm{CO}_{2}}$ in the polystyrene can thus be expressed as weight flow rate ratio.

A large decrease of the pressure into the extruded matter was observed when $\mathrm{scCO}_{2}$ was injected, mainly due to the decrease of melt viscosity [17]. For all experiments, 3-5 $\mathrm{mm}$ outer

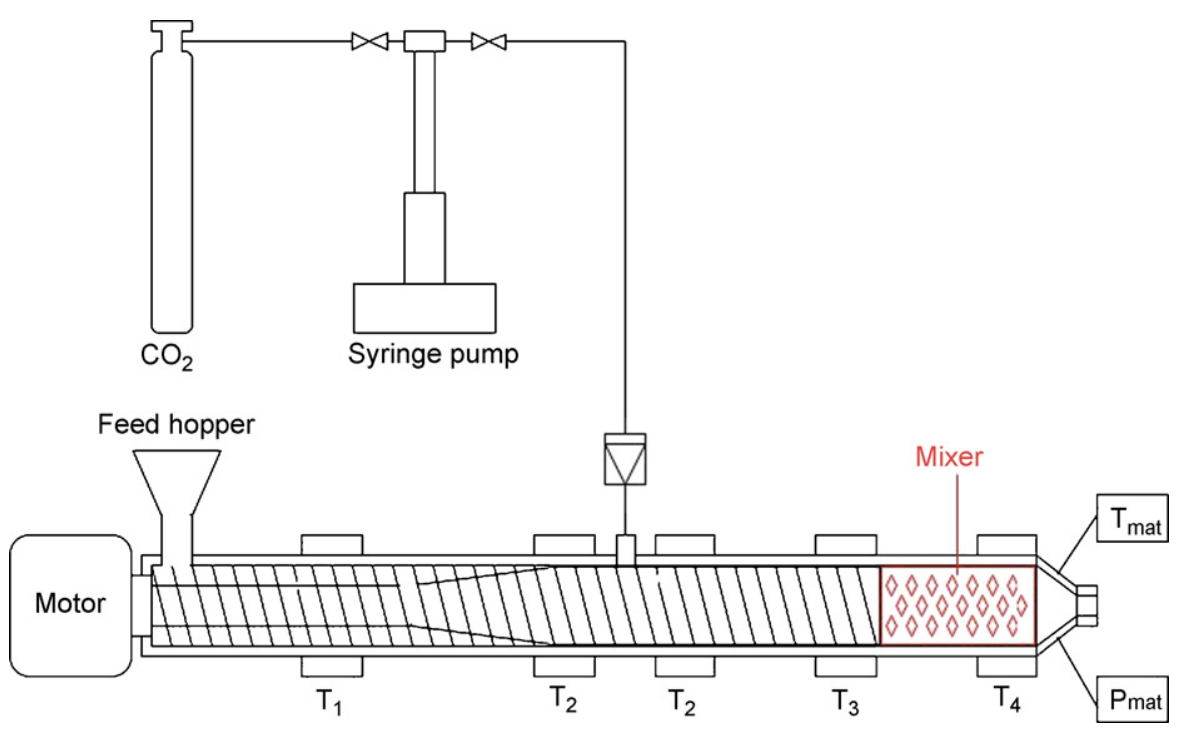

Fig. 1. Flow diagram of the extruder. 
diameter PS cylinders were obtained. Once stable conditions have been established, samples were collected and submitted to two kinds of cooling. The first one consists in leaving the polymer at ambient conditions at about $22{ }^{\circ} \mathrm{C}$. In the second one, material is plunged into a water bath at ambient temperature immediately after its exit from the die.

To study the influence of operating parameters on porous structure, several experiments have been carried out at $12 \mathrm{MPa}$ varying cooling mode, die temperature and $\mathrm{CO}_{2}$ concentration, other parameters being constant. Experiments are time and material consuming and we have thus chosen to study die temperature and $\mathrm{CO}_{2}$ content at three levels to observe the main tendencies of the influence of these operating parameters.

\subsection{Characterization}

Porosity $\varepsilon$ is defined as the ratio of void volume to the total volume of the sample and can be calculated by the following equation:

$\varepsilon=\frac{V_{\mathrm{e}}}{V_{\mathrm{t}}}=1-\frac{V_{\mathrm{m}}}{V_{\mathrm{t}}} \quad$ with $V_{\mathrm{t}}=V_{\mathrm{e}}+V_{\mathrm{m}}$

where $V_{\mathrm{t}}$ is the total volume of the sample, $V_{\mathrm{e}}$ the void volume and $V_{\mathrm{m}}$ is the solid volume. Two methods are used to characterize porosity: the water-pycnometry and the $\mathrm{Hg}$-porosimetry (Autopore III, Micrometerics).

The water-pycnometry allows the measurement of the apparent density $\rho_{\text {app }}$ of expanded samples and thus to calculate the total porosity $\varepsilon$ :

$\varepsilon=1-\frac{\rho_{\mathrm{app}}}{\rho_{\mathrm{PS}}}$

where $\rho_{\mathrm{ps}}$ is the bulk density of raw polystyrene, which corresponds to polystyrene extruded without $\mathrm{CO}_{2}$ injection. This density, also measured by water-pycnometry, is equal to $1 \mathrm{~g} \mathrm{~cm}^{-3}$. (a)

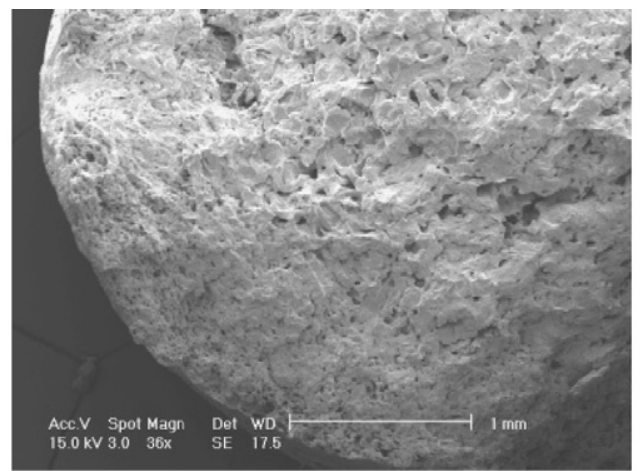

(b)

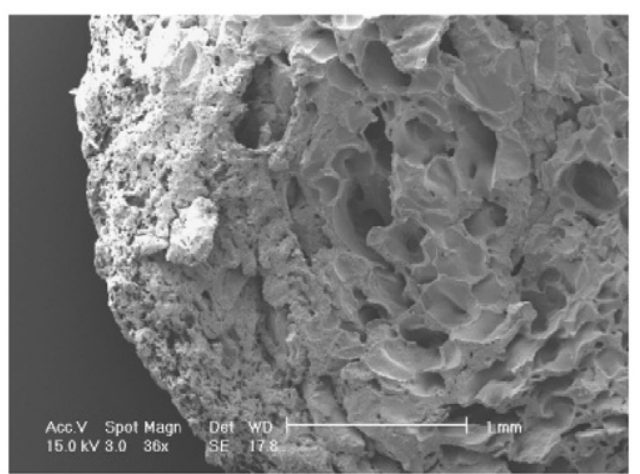

(c)

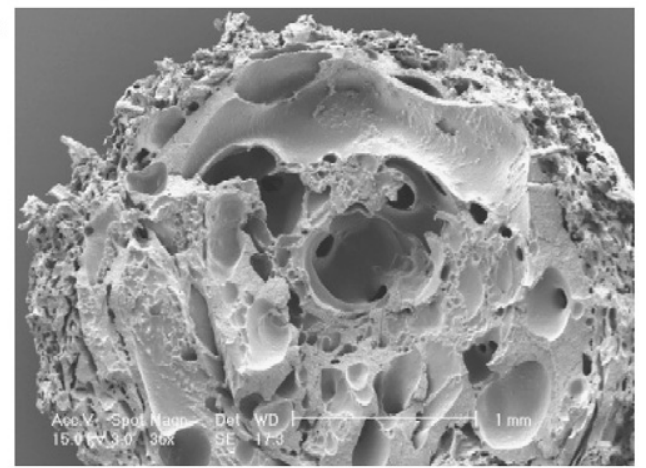

$1 \mathrm{~mm}(\times 35)$
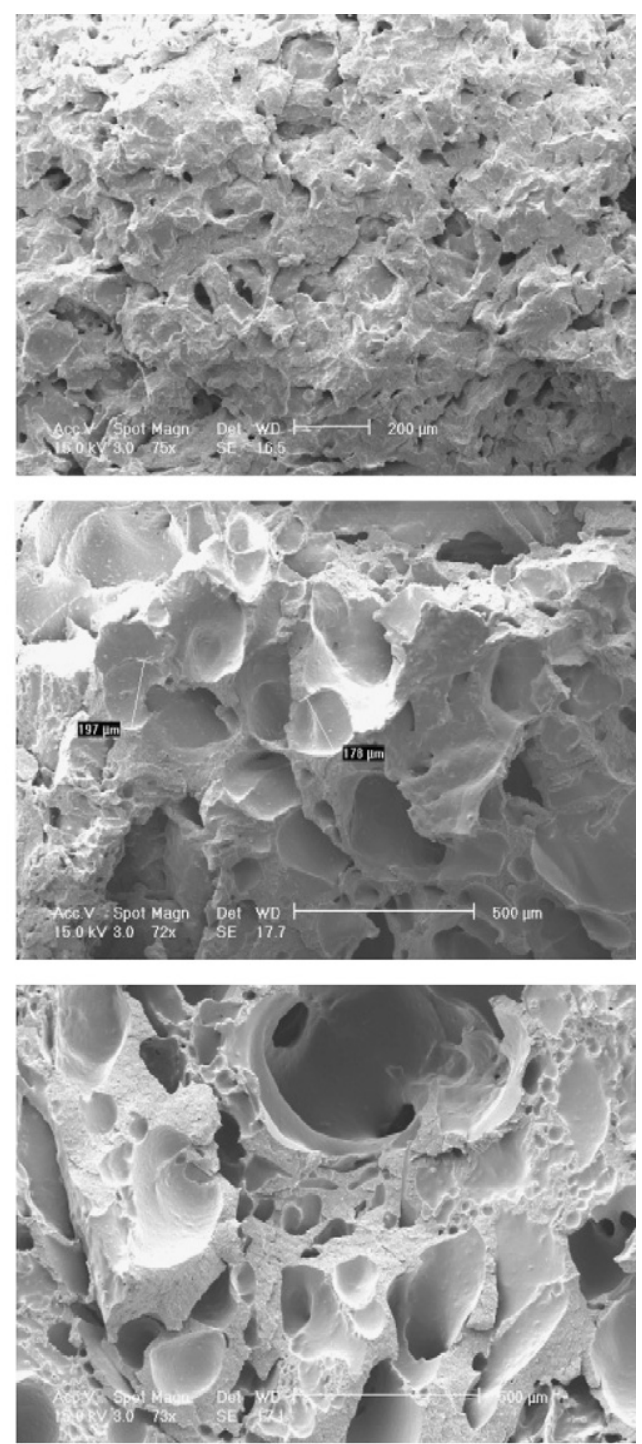

$500 \mu \mathrm{m}(\times 75)$

Fig. 2. SEM pictures of samples cooled in air processed at $P_{\text {mat }}=(12 \pm 1) \mathrm{MPa}, C_{\mathrm{CO}_{2}}=(5 \pm 0.2) \%$ and (a) $T_{\text {mat }}=175^{\circ} \mathrm{C}$; (b) $T_{\text {mat }}=185^{\circ} \mathrm{C}$; (c) $T_{\text {mat }}=200{ }^{\circ} \mathrm{C}$. 
In Hg-porosimetry, mercury is used as penetrating fluid in a calibrated pycnometer. It is forced to enter into the pores by means of an increasing pressure related to the diameter of the filled pore. Each pressure level required to fill the sample provides the diameter $D_{\mathrm{p}}$ and the volume $V_{\mathrm{p}}$ of corresponding pores. In this method, only the opened porosity $\varepsilon_{\text {eff }}$ is filled by mercury and can thus be calculated with the following equation:

$\varepsilon_{\mathrm{eff}}=\frac{\sum V_{\mathrm{p}}}{V_{\mathrm{t}}}$

To quantify the fraction of the total porosity which is opened, an open porosity rate $X_{\text {eff }}$ can be defined as the ratio of the opened porosity to the total porosity:

$X_{\text {eff }}=\frac{\varepsilon_{\text {eff }}}{\varepsilon}$

It has to be noted that a minimal pressure is required to begin a measurement in $\mathrm{Hg}$-porosimetry. This lowest usable pressure corresponds to a maximal value of pore diameter equal to about $200 \mu \mathrm{m}$.

To complete the characterization of the porosity structure, samples were examined by scanning electron microscopy (XL30 ESEM, FEG, Philips).

\section{Results and discussion}

\subsection{Influence of the cooling mode}

Fig. 2 compares three PS samples processed at different die temperatures. All of them have an external skin with a roughly constant thickness. It is probably formed by an effect of hardening during the cooling. The differences appear in the centre of the cylinders. Indeed, with increasing temperature, pores become larger and more irregular. Finally, for highest temperatures, large pores occupy all the central part. This effect is more important in the rod centre, which is more slowly cooled. Moreover, at lower temperature, the porous structure is improved by the addition of the mixer [12].

Table 1 shows the evolution of porosity $\varepsilon$ as a function of temperature. An important increase of $\varepsilon$ occurs from 175 to $185^{\circ} \mathrm{C}$, probably due to growth of the pores which conserve a
Table 1

Porosity $\varepsilon$ at different temperatures $T_{\text {mat }}$ of samples processed at $P_{\text {mat }}=(12 \pm 1) \mathrm{MPa}, C_{\mathrm{CO}_{2}}=(5 \pm 0.2) \%$ and cooling in air

\begin{tabular}{ll}
\hline$T_{\text {mat }}\left({ }^{\circ} \mathrm{C}\right)$ & $\varepsilon(\%)$ \\
\hline 175 & 16 \\
185 & 31 \\
200 & 30 \\
\hline
\end{tabular}

regular shape. Then, porosity $\varepsilon$ remains constant from 185 to $200{ }^{\circ} \mathrm{C}$. It seems that growth is attenuated and that coalescence phenomena are at the origin of the structure observed at $200^{\circ} \mathrm{C}$.

Fig. 3 compares two samples processed in the same operating conditions but cooled by using the two different ways previously described. At this temperature, the influence of the cooling is obvious: the cooling in water allows smaller and homogeneous pores and a porosity reduced from 30 to $19 \%$. Growth and coalescence are attenuated and it is thus important to solidify rapidly the structure to carry out relevant observations on the influence of operating parameters.

\subsection{Effect of die temperature}

Fig. 4 shows SEM pictures of samples obtained at different die temperatures. Increasing the temperature increases the pore size and decreases the pore number. It appears a radial distribution of pore size, with larger pores in the cylinder centre. The shape evolves also with temperature, the pores becoming more regular and finally almost spherical at $220^{\circ} \mathrm{C}$.

Arora et al. [18] have used a batch process to foam PS by using $\mathrm{CO}_{2}$ between 40 and $120^{\circ} \mathrm{C}$. They have also observed fewer and larger pores at higher temperatures. This can be explained by the decrease of the viscosity of the substrate material causing the restrictive force restricting cell growth to decrease and the increase of the diffusivity of $\mathrm{CO}_{2}$ within the substrate. With a continuous process, Park et al. [19] have shown that the improvement of pore structure is obtained at the price of the decrease of expansion. They have thus observed an increase of cell coalescence with increasing die temperature. More recently using also a continuous process, Han et al. [20] have done the same observation, with however coupled effects of pressure and temperature. (a)

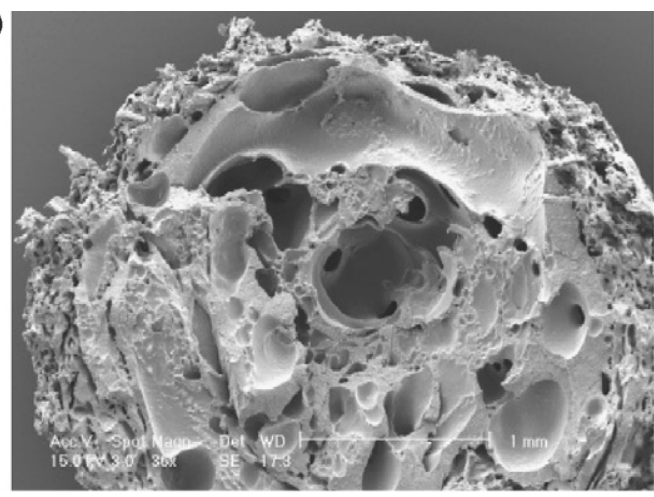

(b)

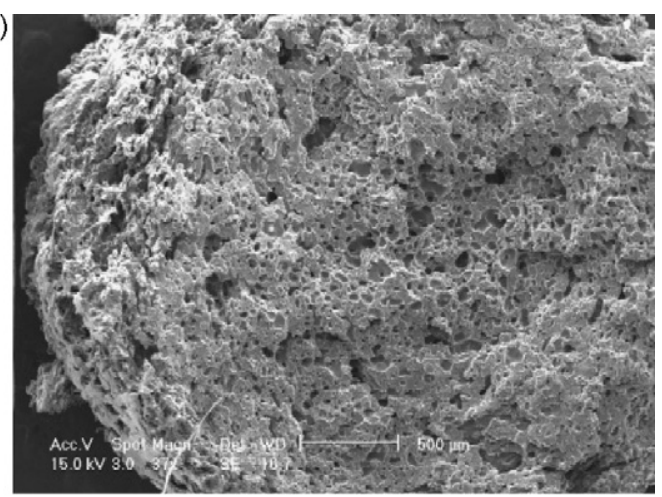

$1 \mathrm{~mm}(\times 35)$

Fig. 3. SEM pictures of samples processed at $P_{\text {mat }}=(12 \pm 1) \mathrm{MPa}, T_{\mathrm{mat}}=200^{\circ} \mathrm{C}, C_{\mathrm{CO}_{2}}=(5 \pm 0.2) \%$ and cooled (a) in air; (b) in water. 

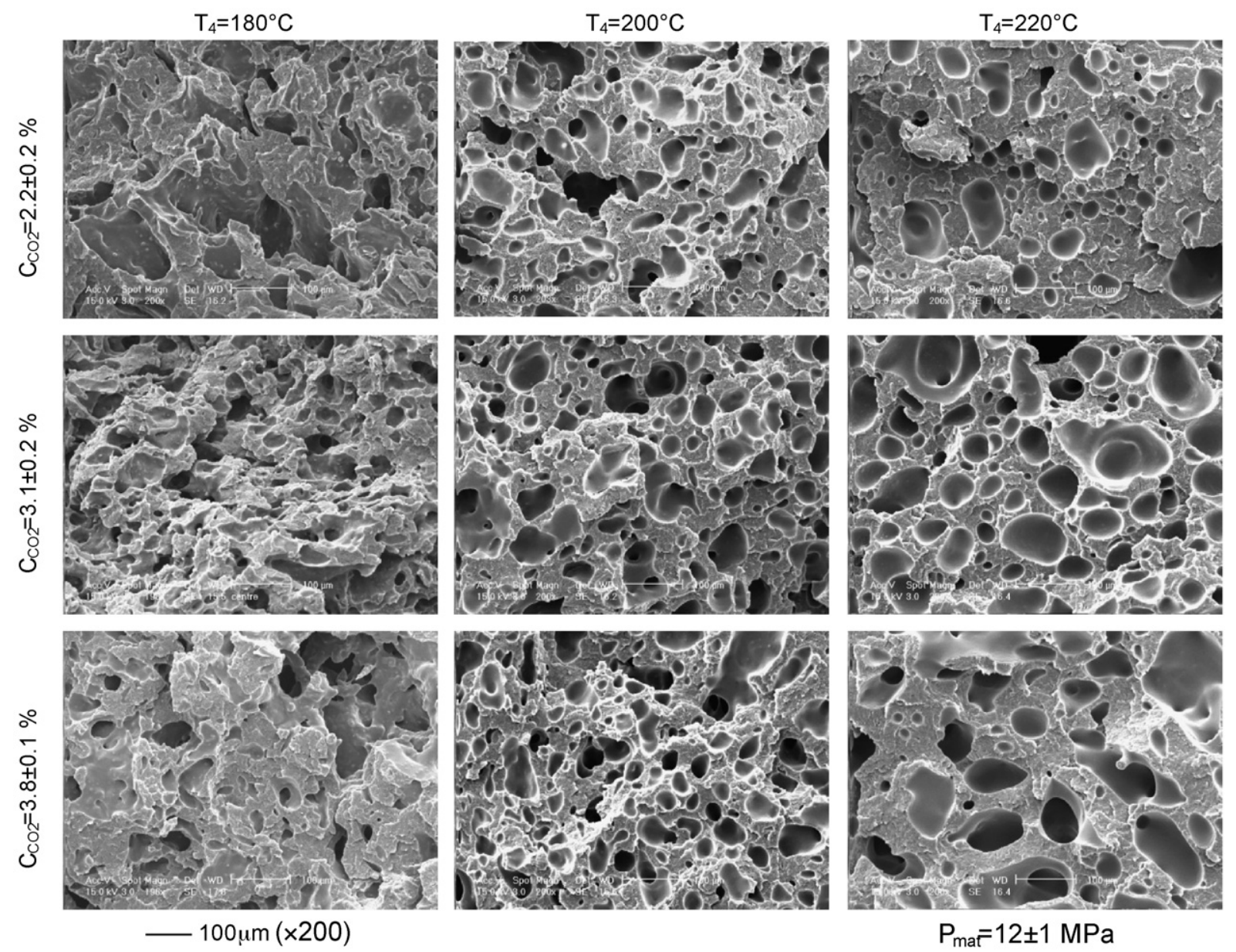

$\mathrm{P}_{\mathrm{ma}}=12 \pm 1 \mathrm{MPa}$

Fig. 4. SEM pictures of samples cooled in water processed at $P_{\text {mat }}=(12 \pm 1) \mathrm{MPa}$.

Indeed, the authors have worked with constant die geometry and, a temperature decrease has involved a pressure drop increase because of the viscosity increase, which may also influence the structure.

The relationship between die temperature and homogenous nucleation rate is complex because many physical properties depend on this temperature. Indeed, by using classical theory, it can be shown that increasing the temperature enhances the homogenous nucleation rate [20]. Thus, as previously observed in the case of air cooling, it seems that the observed evolution cannot be explained by nucleation theory but rather by an increase in the growth and coalescence phenomena, involving fewer and larger pores [18].

Fig. 5 shows the evolution of porosity with temperature. At higher $\mathrm{CO}_{2}$ concentration, total porosity $\varepsilon$ increases from 180 to $200^{\circ} \mathrm{C}$ and then remains almost constant from 200 to $220^{\circ} \mathrm{C}$. At the lowest $\mathrm{CO}_{2}$ concentration, the temperature exhibits no more influence on porosity. At the same time, opened porosity $\varepsilon_{\text {eff }}$ decreases slowly with increasing temperature (Fig. 6). This leads to the decrease of the opened porosity rate $\varepsilon_{\text {eff }}$ from $68 \%$ at $180^{\circ} \mathrm{C}$ to $37 \%$ at $220^{\circ} \mathrm{C}$ (Fig. 7). Growth is therefore the predominant effect at lower temperatures, while cell coalescence occurs at higher temperatures, involving the closing of these cells.
The pore size distribution obtained by $\mathrm{Hg}$-porosimetry is represented at different temperatures on Figs. 8 and 9. At $180^{\circ} \mathrm{C}$, diameter of pores is between 5 and $20 \mu \mathrm{m}$. When the temperature increases, pore size increases to values higher than $200 \mu \mathrm{m}$, which is the limit of the apparatus. This evolution confirms the former conclusion that coalescence and growth phenomena occur when temperature increase and lead to larger porosity.

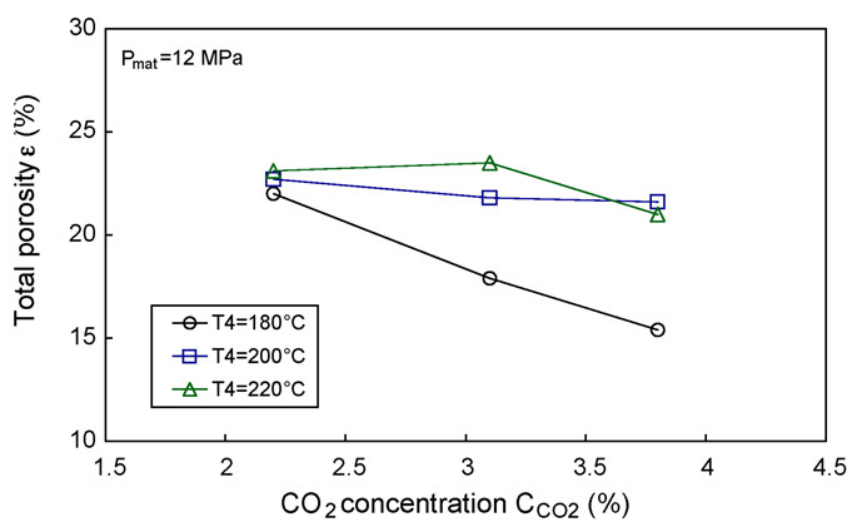

Fig. 5. Total porosity $\varepsilon$ as function of $\mathrm{CO}_{2}$ concentration at different temperatures. 


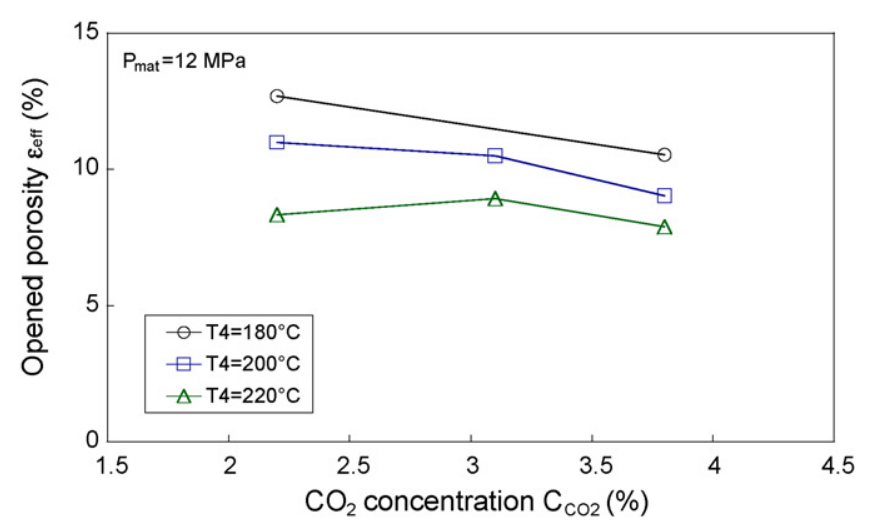

Fig. 6. Opened porosity $\varepsilon_{\text {eff }}$ as function of $\mathrm{CO}_{2}$ concentration at different temperatures.

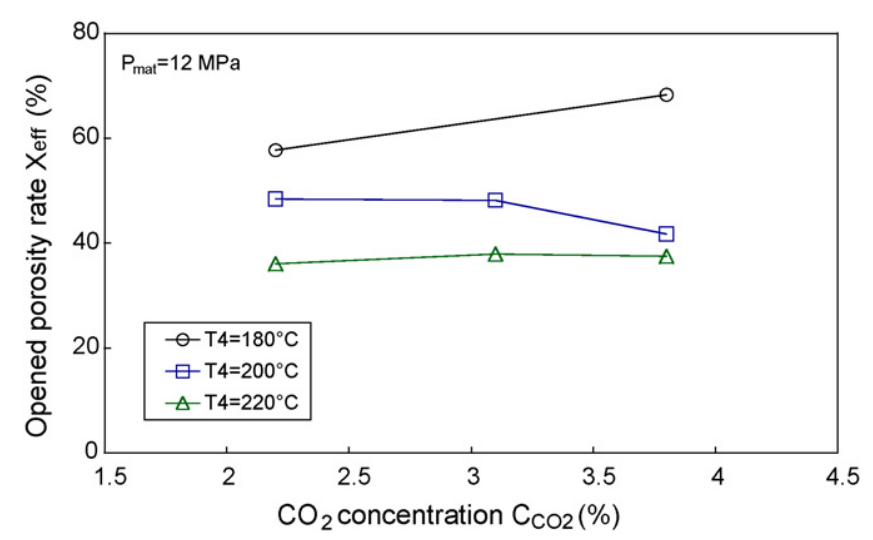

Fig. 7. Opened porosity rate $X_{\text {eff }}$ as function of $\mathrm{CO}_{2}$ concentration at different temperatures.

\subsection{Effect of $\mathrm{CO}_{2}$ weight ratio}

On SEM pictures, the effect of $\mathrm{CO}_{2}$ concentration is less obvious than that of the die temperature (Fig. 4). On Figs. 5 and 6, it can be seen that total porosity $\varepsilon$ and opened porosity $\varepsilon_{\text {eff }}$ decrease slightly with increasing $\mathrm{CO}_{2}$ concentration, with however a higher effect at lower temperature. This finally leads to an opened porosity rate $\varepsilon_{\text {eff }}$ almost constant (Fig. 7). Pore size distributions obtained by $\mathrm{Hg}$-porosimetry confirm the lim-

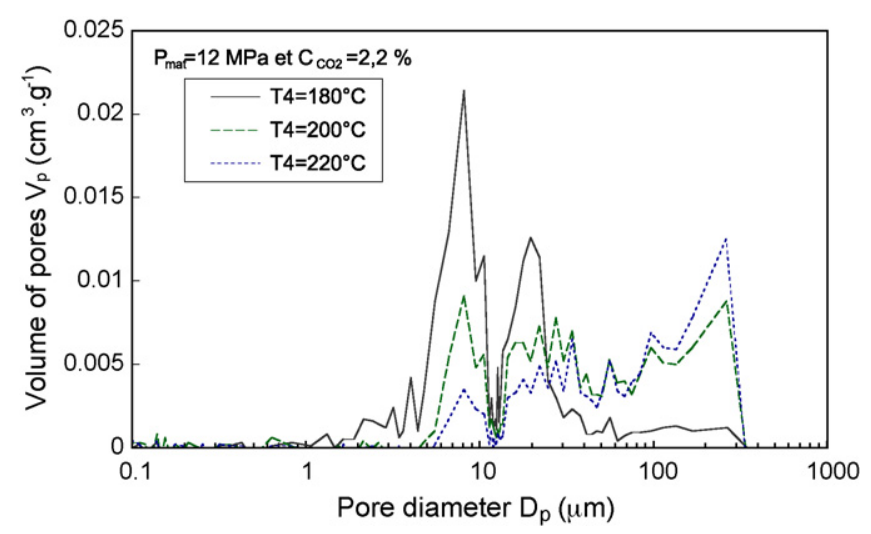

Fig. 8. Pore size distribution with $2.2 \%$ of $\mathrm{CO}_{2}$ at different temperatures.

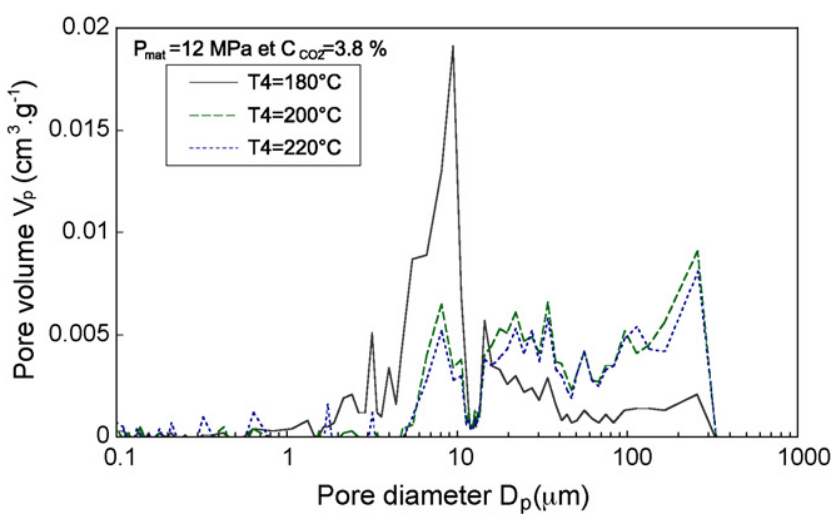

Fig. 9. Pore size distribution with $3.8 \%$ of $\mathrm{CO}_{2}$ at different temperatures.

ited influence of $\mathrm{CO}_{2}$ concentration, as for instance at $200^{\circ} \mathrm{C}$ (Fig. 10).

It is clear that increasing $\mathrm{CO}_{2}$ concentration increases nucleation rate [20]. However, $\mathrm{CO}_{2}$ concentration increase involves also the modification of other key physical variables, such as for instance properties like viscosity or surface tension [7-10]. This difficulty is well illustrated by Han et al. [21] who have also studied the effect of $\mathrm{CO}_{2}$ concentration. By means of a computational fluid dynamics program, these authors have represented profiles of pressure and saturation $\mathrm{CO}_{2}$ fraction along the nozzle. Because of their constant die geometry, the increase of $\mathrm{CO}_{2}$ concentration was coupled with a pressure decrease. They have then found that the more $\mathrm{CO}_{2}$ in the melt, the earlier the bubbles begin to nucleate and grow. In other words, a high $\mathrm{CO}_{2}$ content gives more nuclei, but a longer time for bubble growth. However, during their experiments, it was noted that both the pressure and the pressure drop rate are independent of $\mathrm{CO}_{2}$ content. Finally, they observed that, at low $\mathrm{CO}_{2}$ concentrations, cell size decreases and cell density increases with increasing $\mathrm{CO}_{2}$ content. While at high $\mathrm{CO}_{2}$ concentrations (above $4 \%$ ), cell size tends to be independent of $\mathrm{CO}_{2}$ content, probably because of extra gas, which is not used to nucleate cells. If we translate these experimental observations in terms of total porosity, no clear trend appears. Indeed, cell size increase and cell density decrease show opposite effects on total porosity.

In this work, no significant influence of $\mathrm{CO}_{2}$ concentration has been observed. However, PS- $\mathrm{CO}_{2}$ blend is theoretically in a

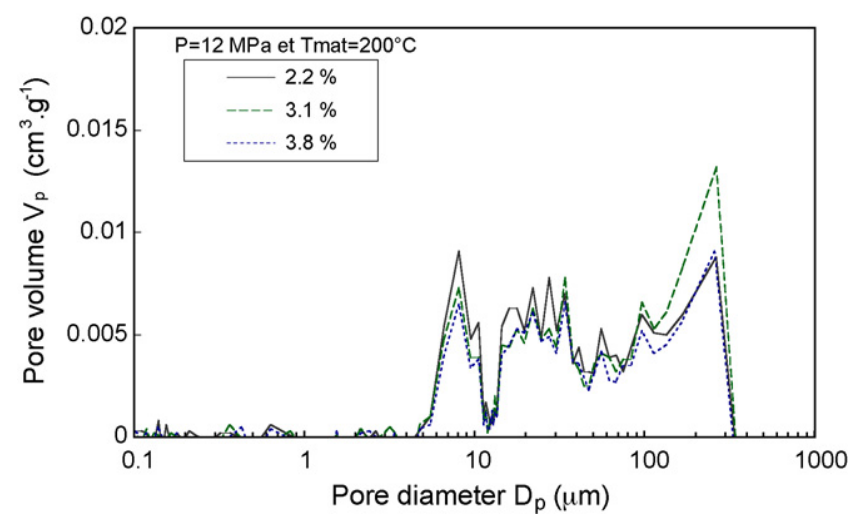

Fig. 10. Pore size distribution at $200{ }^{\circ} \mathrm{C}$ and different $\mathrm{CO}_{2}$ concentrations. 
single phase at thermodynamic equilibrium, as $\mathrm{CO}_{2}$ weight solubility was estimated to be at about $5 \%$ at $180{ }^{\circ} \mathrm{C}$ and $12 \mathrm{MPa}$ [15]. Thus, as observed by Han et al. [21], it seems that a part of injected $\mathrm{CO}_{2}$ remains as extra gas and is not used to nucleate cells. Furthermore, higher $\mathrm{CO}_{2}$ content than studied range usually causes unstable polymer flow with oscillating pressure, what would tend to confirm this assumption.

\section{Conclusion}

A process based on extrusion coupled with the use of supercritical carbon dioxide $\left(\mathrm{scCO}_{2}\right)$ was implemented. $\mathrm{scCO}_{2}$ modifies the rheological properties of the material in the barrel of the extruder and acts as a blowing agent during the relaxation at the passage through the die. A novel experimental device based on a single-screw extruder was developed. It allows the injection of $\mathrm{scCO}_{2}$ into extruded melt, the mixing of both compounds and the creation of porosity into the extrudated polymer. In this work, it was applied to polystyrene (PS). Operating temperatures and mechanical constraints within the extruded material were reduced by the injection of $\mathrm{CO}_{2}$. The effects of cooling mode, die temperature and $\mathrm{CO}_{2}$ concentration on material porosity were studied. PS with porosity from 15 to $25 \%$ was manufactured. A rapid cooling is important to solidify the structure. Increasing die temperature increases growth and coalescence phenomena, and thus increases total porosity and pore diameter. Finally, this parameter allows the control of the porosity structure. $\mathrm{CO}_{2}$ concentration shows no significant influence. It was explained by the fact that a part of injected $\mathrm{CO}_{2}$ remains as extra gas and is not used to nucleate cells.

\section{References}

[1] C. Rauwendaal, Polymer Extrusion, Hanser Publishers, München, 2001.

[2] C. Eckert, B. Knutson, P. Debenedetti, Supercritical fluids as solvents for chemical and materials processing, Nature 383 (1996) 313-383.

[3] S.G. Kazarian, Polymer processing with supercritical fluids, Polym. Sci. Ser. C 42 (2000) 78-101.

[4] S.P. Nalawade, F. Picchioni, L.P.B.M. Janssen, Supercritical carbon dioxide as a green solvent for processing polymer melts: processing aspects and applications, Prog. Polym. Sci. 31 (2006) 19-43.
[5] J.H. Aubert, Solubility of carbon dioxide in polymers by the quartz crystal microbalance technique, J. Supercrit. Fluids 11 (1998) 163-172.

[6] Y. Sato, K. Fujiwara, T. Takikawa, S. Takishima, H. Masuoka, Solubilities and diffusion coefficients of carbon dioxide and nitrogen in polypropylene, high-density polyethylene, and polystyrene under high pressures and temperatures, Fluid Phase Equilib. 162 (1999) 261-276.

[7] D. Gourgouillon, H.M.N.T. Avelino, J.M.N.A. Fareleira, M. Nunes Da Ponte, Simultaneous viscosity and density measurement of supercritical $\mathrm{CO}_{2}$-saturated PEG 400, J. Supercrit. Fluids 13 (1998) 177-185.

[8] P.D. Condo, I.C. Sanchez, C.G. Panayiotou, K.P. Johnston, Glass transition behavior including retrograde vitrification of polymers with compressed fluid diluents, Macromolecules 25 (1992) 6119-6127.

[9] H. Li, L.J. Lee, D.L. Tomasko, Effect of carbon dioxide on the interfacial tension of polymer melts, Ind. Eng. Chem. Res. 43 (2004) 509-514.

[10] H. Park, C.B. Park, C. Tzoganakis, K.H. Tan, P. Chen, Surface tension measurement of polystyrene melts in supercritical carbon dioxide, Ind. Eng. Chem. Res. 45 (2006) 1650-1658.

[11] J.H. Han, C.D. Han, Bubble nucleation in polymeric liquids. II. Theoretical considerations, J. Polym. Sci. Part B 28 (1990) 743-761.

[12] M. Sauceau, S. Puissant, D. Richon, J. Fages, Développement de procédés d'extrusion assistés par un fluide supercritique, in: Groupe Français de Rhéologie (Ed.), Proceedings of the 39th Colloque du Groupe Francais de Rhéologie, 2004, p. 248.

[13] B. Vergnes, S. Puissant, Extrusion monovis (partie 1), Techniques de l'Ingénieur traité Plastiques et Composites AM 3650 (2002) 1-16.

[14] D.-Y. Peng, D. Robinson, A new two-constant equation of state, Ind. Eng. Chem. Fundam. 15 (1976) 59-64.

[15] Y. Sato, M. Yurugi, K. Fujiwara, S. Takishima, H. Masuoka, Solubilities of carbon dioxide and nitrogen in polystyrene under high temperature and pressure, Fluid Phase Equilib. 125 (1996) 129-138.

[16] Y. Sato, T. Takikawa, S. Takishima, H. Masuoka, Solubilities and diffusion coefficients of carbon dioxide in poly(vinyl acetate) and polystyrene, J. Supercrit. Fluids 19 (2001) 187-198.

[17] C. Kwag, C.W. Manke, E. Gulari, Rheology of molten polystyrene with dissolved supercritical and near-critical gases, J. Polym. Sci. Part B 37 (1999) 2771-2781.

[18] K.A. Arora, A.J. Lesser, T.J. McCarthy, Preparation and characterization of microcellular polystyrene foams processed in supercritical carbon dioxide, Macromolecules 31 (1998) 4614-4620.

[19] C.B. Park, A.H. Behravesh, R.D. Venter, Low density microcellular foam processing in extrusion using $\mathrm{CO}_{2}$, Polym. Eng. Sci. 38 (1998) 1812-1823.

[20] X. Han, K.W. Koelling, D.L. Tomasko, L.J. Lee, Effect of die temperature on the morphology of microcellular foams, Polym. Eng. Sci. 43 (2003) $1206-1220$.

[21] X. Han, K.W. Koelling, D.L. Tomasko, L.J. Lee, Continuous microcellular polystyrene foam extrusion with supercritical $\mathrm{CO}_{2}$, Polym. Eng. Sci. 42 (2002) 2094-2106. 